\title{
The Quantitative Checklist for Autism in Toddlers (Q-CHAT): A preliminary psychometric study in Chile
}

Short Title: Q-CHAT Preliminary Psychometric Study in Chile

Gabriel Gatica-Bahamonde ${ }^{1 * \pi}$, Paula Alarcón ${ }^{2 \pi}$, Alejandra Méndez Fadol ${ }^{1 \&}$, Carrie Allison $^{3 \&}$, Simon Baron-Cohen $^{3 \&}$, Andres Roman-Urrestarazu $3,4,5^{*} \&$

${ }^{1}$ Department of Psychiatry and Mental Health, Faculty of Medicine, Universidad de La Frontera, Temuco, Chile

${ }^{2}$ Department of Psychology, Universidad de La Frontera, Temuco, Chile

${ }^{3}$ Autism Research Centre, Department of Psychiatry, University of Cambridge, Cambridge, United Kingdom

${ }^{4}$ Institute of Public Health, University of Cambridge, Cambridge, United Kingdom

${ }^{5}$ Faculty of Health, Medicine and Life Sciences, Department of International Health, University of Maastricht, Maastricht, Netherlands

*Corresponding authors:

aer56@medschl.cam.ac.uk (AR-U); gabriel.gatica@ufrontera.cl (GG-B)

II These authors contributed equally to this work.

\& These authors also contributed equally to this work. 


\begin{abstract}
The aim of this study was to examine the psychometric properties of an adapted version of the Quantitative Checklist for Autism in Toddlers (Q-CHAT), an early screening tool that quantifies autistic traits dimensionally, in a community sample of Chilean children aged 18-24 months. An intentional non-probabilistic sampling was used. All primary caregivers of children aged 18-24 months who attended health check-up at four primary care clinics in Chile's Araucanía region during the study period were invited to participate. One hundred and eighty-eight toddlers were screened. Evidence of construct validity was determined through Exploratory Factor Analysis (EFA), evidence of convergent validity with the Modified Checklist for Autism in Toddlers, Revised with Follow-Up (M-CHAT-R/F), and evidence of reliability through internal consistency and test-retest. The EFA showed a two-factor structure, which explained $42.2 \%$ of the variance: "Restrictive and Repetitive Patterns" (factor 1), and "Communication and Social Interaction" (factor 2). The total Q-CHAT scores correlated positively and significantly with the total MCHAT-R/F scores $(\mathrm{r}=0.59, \mathrm{p}<0.01)$ with a large effect size. Internal consistency was acceptable for the scale in general $(\alpha=0.74)$, acceptable for factor $1(\alpha=0.76)$ and good $(\alpha=0.85)$ for factor 2 . Regarding test-retest stability, the intraclass correlation coefficient was good $(\mathrm{ICC}=0.86, \mathrm{p}<0.001)$. In terms of the factor structure evidenced by the EFA, the two factors are theoretically consistent with the current diagnostic criteria of the DSM-5. The evidence of validity and reliability of QCHAT is encouraging when considering its use as an early detection tool in Chile.
\end{abstract}

Keywords: Autism Spectrum Conditions, Early Detection, Screening, Factor Analysis, Q-CHAT, Autism 


\section{Introduction}

Autism Spectrum Conditions (hereafter 'autism') are a group of neurodevelopmental conditions characterized by persistent difficulties in communication and social interaction, and the presence of restricted and repetitive patterns of behavior, interests, and activities (1). Recent studies show prevalence around 16.8/1,000 (2). In Chile there are no prevalence studies of autism, but according to estimates by the Ministry of Health of Chile (3) in 2007 the incidence of autism would be 2,156 cases.

Early detection of autism signs allows early referral to intervention programs (4). There is evidence that personalized early detection and management improves the prognosis and quality of life for children and their families $(5,6)$, that interventions are more effective at early ages (7), and that they result in decreased costs to both families and the health care system $(8,9)$. Despite the above, delays in the early detection of autism have been described. Sheldrick, Maye, \& Carter (10) analyzed the results of national health surveys in the United States and report that the diagnosis was made after 6 years in $30 \%-50 \%$ of cases.

Over the past two decades, evidence regarding the early signs of autism has proliferated based on retrospective studies of children with the condition, and through the prospective study of children with an increased likelihood for autism $(11,12)$. Children subsequently diagnosed with autism present predictive signs of autism from the age of 6 months (13). These signs are specific for the detection and differentiation from other developmental disorders as early as 12 months of age (12) .

The study of these early signs has allowed the delimitation of "red flags" for autism, which guide clinicians and professionals in the identification and referral of children who may be on the autistic trajectory (14). Early signs include deficits in several areas: joint attention, pretend play, affective response, response to name, social smile, verbal and non-verbal communication, 
imitation, motor development and unusually repetitive behaviors, eye gaze, eye contact, pointing gestures, among others (15-20).

There is empirical evidence suggesting that the early signs of autism can be measured and have been incorporated in the development of screening tests for the early detection of autism (18), through parents or caregiver report. An autism screening tool is a brief evaluation that can be administered to a given child population to detect those who may have the condition (21). Screening is conducted with the aim of identifying children who can be referred for early intervention programs, in the critical period of development from 18 to 24 months of age $(22,23)$. Early detection by screening could reduce the time between referral and diagnosis to intervention by up to 68 to 70 percent, respectively (24). Despite the above, even a very small percentage of parents are alerted to their child's developmental problems after the application of a specific screening test for Autism (25).

Among the most widely used and studied autism screening tools are the Checklist for Autism in Toddlers (CHAT) (26), the Modified Checklist for Autism in Toddlers (M-CHAT) (27), and the Modified Checklist for Autism in Toddlers, Revised With Follow-up (M-CHAT-R/F) (28). All of these conceptualize autistic traits as categorical variables, using a binary scoring system that uses dichotomous "yes/no" items. This categorical approach has the potential limitation of identifying the most obvious autistic children, and not identifying the less clear cases (29).

In contrast, the Quantitative CHecklist for Autism in Toddlers, Q-CHAT (30) is an autism screening tool that conceptualizes the autism spectrum on a continuous scale, taking a dimensional approach to the identification of autistic traits $(14,29,31)$. From a theoretical point of view, this proposal is consistent with the conceptual evolution of autism and its consideration as a continuous and heterogeneous dimension of symptoms and traits within the spectrum of autism and within the general population (32). The ability to dimensionally measure autistic traits using 
the Q-CHAT is supported by evidence showing that test scores are typically distributed across diverse populations studied (29-31,33-36).

\section{Q-CHAT psychometric studies}

In the original study by Allison et al. (30), 160 caregivers of autistic children (clinical sample) and 776 caregivers of unselected children (community sample) completed the Q-CHAT. Significantly higher total Q-CHAT scores were reported in the clinical group compared to the community group. Scores on the Q-CHAT followed a near normal distribution in both the community and the clinical group. Boys scored significantly higher than girls in the community group, but not in the clinical group. Internal consistency showed a Cronbach`s value of 0.67 in the control group and $\alpha=0.83$ in the autism group. Test-retest reliability measured by the Intraclass Correlation Coefficient was good $(I C C=0.82, p<0.0001)$. In a later study, Allison et al. (2012) developed an abbreviated version (Q-CHAT-10), which contains the 10 items that best discriminated autistic children from population controls. The psychometric values reported were good, evidenced by high internal consistency $(\alpha=0.88)$ and a significant correlation with the full Q-CHAT $(r=0.79, p=0.0001)$, with a large effect size.

In Latin America, Villalba (37) examined the psychometric characteristics of the Q-CHAT in a sample of 231 Colombian children (49 autism and 182 with neurotypical development). The internal consistency was acceptable for the general scale $(\alpha=0.71)$. Mohammadian et al. (34) studied the Q-CHAT in a sample of 100 Iranian children (50 autism and 50 neurotypical). Like the study by Allison et. al. (30), total Q-CHAT scores were normally distributed across the sample and boys scored significantly higher than girls in the community group, but not in the autism group. Internal consistency was good for the scale $(\alpha=0.88)$ and test-retest stability was excellent $(r=0.99, p<0.01)$. Ruta et al. (35) also studied the psychometric properties, score distribution and external validity of the Q-CHAT in a sample of 126 Italian children with 
neurotypical development (NTD), 130 autistic children and 50 children with Intellectual Disability (ID). Q-CHAT scores were normally distributed in all groups. The internal consistency of the Q-CHAT in all the samples combined and in the autism group was $\operatorname{good}(\alpha=0.87$ and $\alpha=$ 0.84, respectively), while it was acceptable for the NTD and ID groups ( $\alpha=0.7$ for both groups).

The Q-CHAT has also been studied in specific risk populations. Wong et al. (36) used the QCHAT to measure autistic traits in a sample of preterm infants. Q-CHAT total score showed a normal distribution. This preterm group had higher Q-CHAT scores than in the population sample published by Allison et al. (30) (Mean difference $=7.0(95 \% \mathrm{CI}) ; \mathrm{p}<0.001)$ and no difference was found in Q-CHAT score between boys and girls in the preterm group. Modi et al. (33), also reported Q-CHAT data in a group of preterm infants. They reported a normal distribution in the total Q-CHAT score, and the total Q-CHAT score was significantly higher than in the general population reported by Allison et al. (30). This study also did not find a significant sex difference in Q-CHAT score between boys and girls. Raza et al. (38) used the QCHAT-10 version (14), to evaluate its potential use as a screening tool for children with an increased likelihood of autism (siblings of children diagnosed with autism) at the age of 18 and 24 months. The authors reported a sensitivity and specificity of 0.75 and 0.63 respectively at 18 months and 0.71 and 0.65 at 24 months, respectively. Recently, Roman-Urrestarazu et al.(39) have provided evidence regarding the implementation of Q-CHAT-10 in an autism screening programme in Chile. They applied this instrument to a sample of 287 children (Controls: $\mathrm{n}=125$; Developmental Delay: $n=149$; Autism: $n=13$ ) from 18 to 30 months. They reported high internal consistency ( $\alpha=0.85)$, Sensitivity of $92.86 \%$ and Specificity of $76.86 \%$. No evidence of the psychometric characteristics of the Q-CHAT full item format was reported.

The factor structure of Q-CHAT has been reported by Magiati et al. (31), who evaluated the psychometric properties of this tool in an community sample of children at 18 months $(n=368)$ 
and 24 months $(n=396)$. Exploratory Factor Analysis (EFA) and Confirmatory Factor Analysis (CFA) were performed, finding three factors, which explained $38.1 \%$ of the variance: Factor 1 "Social/Communication traits", Factor 2 "Non-Social/Behavioral traits" and Factor 3 "Speech/Language traits". Three items were excluded from the resulting factor structure in the EFA, because their factor loadings were $\leq 0.3$ (items 3, 13 and 14). Total Q-CHAT score was normally distributed in both groups (18 and 24 months). Internal consistency at 24 months was suboptimal for the total scale and for factor 3 ( $\alpha=0.60$ and $\alpha=0.53$, respectively) and adequate for factors 1 and 2 ( $\alpha=0.75$ and $\alpha=0.71$, respectively). Subsequently, Ruta et al., (29) explored the psychometric properties and factor structure of Q-CHAT in an community sample of 2400 Italian children aged 18-24 months in routine well-baby check-ups. They reproduced the EFA procedure performed by Magiati et al. (31), obtaining a three-factor solution, which explained $61 \%$ of the variance: Factor 1 "Non-social/Autistic behavior traits"; Factor 2 "Speech/Language"; Factor 3 "Joint Attention/Non-verbal communication". Five items were excluded model (items 2, 9, 13, 14 and 21), since their factor loadings were less than 0.3 . The internal consistency of the entire scale was suboptimal $(\alpha=0.68)$. For each factor, Cronbach's alpha reported was 0.73 (factor 1), 0.64 (factor 2) and 0.63 (factor 3).

The evidence reported above supports the using the Q-CHAT as a dimensional measure to assess autistic traits in unselected samples (29-31,37), making it a candidate tool for early detection of autism in community samples.

The overall objective of this study to examine the psychometric characteristics of a Chilean-adapted version of the Quantitative Checklist for Autism in Toddlers (Q-CHAT) in a group of unselected children (community sample). This version was administered to caregivers of children, aged 18-24 months, in four primary care polyclinics of the Araucanía Sur Health Service, Chile. The specific objectives of the present study were: a) To determine evidence of 
construct validity of the adapted version of Q-CHAT, through Exploratory Factor Analysis (EFA); b) to determine evidence of convergent validity of the adapted version of the Q-CHAT, with the Modified Checklist for Autism in Toddlers, Revised with Follow-up (M-CHAT-R/F); and c) to determine evidence of reliability of the adapted version of Q-CHAT, through internal consistency of its items and test-retest reliability.

\section{Methods}

\section{Participants}

A study with a descriptive correlational design was carried out. An intentional nonprobabilistic sampling was used. All primary caregivers of children aged 18-24 months who attended health check-up at four primary care clinics in Chile's Araucanía region during the study period were invited to participate in the study $(\mathrm{n}=588)$. One hundred and eighty-eight $(32 \%)$ caregivers agreed to participate. This sample was screened by developmental nurses. The mean age of the children evaluated was 20.51 months (median=20, range $18-24, \mathrm{SD}=2.4$ ), where 53.7 $\%(\mathrm{n}=101)$ were males. $77.1 \%(\mathrm{n}=145)$ lived in urban sectors and $93.1 \%$ of the children belonged to families that had incomes below the 75 th percentile of Chilean households, equivalent to less than US\$1,140 (40). The mean age of caregivers was 29.3 years (median=29, range 18-49, $\mathrm{SD}=6.9)$. Of the caregivers who responded to the Q-CHAT, 89.4\% $(\mathrm{n}=168)$ were mothers of the children, $7.4 \%(n=14)$ were fathers, and 3.2\% $(n=6)$ were other caregivers. $75.5 \%(n=142)$ of the caregivers had 12 or more years of schooling. Table 1 summarizes the socio-demographic characteristics of the sample.

The inclusion criteria were: (a) being between 18 and 24 months of age at the time of the assessment, (b) attending routine health checks at primary care health centres accompanied by the primary caregiver(s). The primary caregiver is understood to be the adult(s) in charge of the young child's daily care (41). The criteria for exclusion were: (a) not being accompanied by the 
primary caregiver(s), and (b) presenting a genetic or neurological condition incompatible with the identification of the assessed behaviors (for example: severe gait disturbance, cerebral palsy, among others).

Table 1. Socio-demographic characteristics of the sample studied ( $N=188)$

\begin{tabular}{lcc}
\hline & $\mathrm{N}$ & $\%$ \\
\hline Gender & 101 & 53.7 \\
Male & 87 & 46.3 \\
Female & 73 & 38.8 \\
Go to the nursery & & \\
Family History & 19 & 10,1 \\
$\quad$ Epilepsy & 28 & 14,9 \\
Language Disorder & 24 & 12,8 \\
Learning Disorder & 13 & 6,9 \\
Intellectual Disability & 21 & 11,2 \\
Psychiatric Disorder & 9 & 4,8 \\
Autism Spectrum Disorder & & \\
Location of the house & 145 & 77,1 \\
Urban & 41 & 21,8 \\
Rural & & \\
Caregiver's Education Level & 12 & 6,4 \\
Basic Incomplete & 8 & 5,3 \\
Basic Complete & 24 & 12,8 \\
Secondary Incomplete & 93 & 49,5 \\
Secondary Complete & 25 & 13,3 \\
Superior Technical & 24 & 12,8 \\
Superior University & & \\
Employment status & 104 & 55,3 \\
Employed & 71 & 37,8 \\
Unemployed & & \\
Family income & 16 & 3,5 \\
Less than \$USD190 & 70 & 37,2 \\
\$US 190 - \$US 380 & 60 & 15,4 \\
\$US 380 - \$US 630 & 29 & 3,7 \\
\$US 630 - \$US 1,140 & 5 & \\
\$US 1,140 - \$US 1,500 & 6 & \\
Over \$US 1,500 & & \\
\hline
\end{tabular}

\section{Instruments}

The Quantitative CHecklist for Autism in Toddlers (Q-CHAT) (30).

The Q-CHAT is a 25-item, parent- or caregiver-reporting scale designed as an autism screening instrument for children aged 18-24 months. The items are scored on a 5-point Likerttype scale (0-4), where higher scores indicate greater autistic traits. Each item is accompanied by 
a color illustration, which seeks to increase comprehensibility. Items that were not answered or were answered in an unclear way were scored as 0 and questionnaires with more than 6 incomplete answers were excluded from the analysis. The sum of each item score comprises the total Q-CHAT score, ranging from a minimum of 0 to a maximum of 100 points. Total Q-CHAT score $\geq 38$ was established as the autism risk score, considering the values reported by Allison et al. (30) in the autism group (mean score=51.8, $\mathrm{SD}=14.3$ ).

To obtain a linguistically and culturally adapted version for Chile, a pilot study was conducted using a rational analytical adaptation procedure (42). Three translations into Spanish were made by independent translators and then a panel of experts synthesized the translations into a test version, which was subjected to a pilot study. A qualitative, descriptive, multi-case design was used (43). Sixteen caregivers of study age children participated. Psychology students conducted focused interviews with each of the participants using aspects of the "Think Aloud" protocol (44), in order to explore the experiences and meanings given by the caregivers to each item. The Reading Comprehension Level (RCL) was estimated for each caregiver (45). The items that presented greater difficulties in comprehension were items 8, 9, 10, 11, 17, 18, 23, 24 and 25. Two specific statements, items 10 and 18, were those which presented the greatest difficulties in understanding. Based on the findings reported, graphic and grammatical adjustments were made to the items, resulting in an adapted version of the Q-CHAT (To review and download the full adapted version, see S1 File).

The Modified CHecklist for Autism in Toddlers, Revised with Follow-Up (M-CHAT-R/F)_(28).

The Chilean version of M-CHAT-R/F was used (46). M-CHAT-R/F is a 2-stage autism screening scale with 20 items for parents of children aged 16 to 30 months. Items are scored according to dichotomous YES/NO responses, with 1 point assigned for each "NO" response, indicating the presence of an autistic trait. For items 2, 5, and 12, the "YES" response indicates 
the presence of an autistic trait which score 1 . The sum total of scores on each item gives the total M-CHAT-R/F score, ranging from 0 to 20 . Scores $\geq 3$ indicate possibility of autism. If the score is between 3 and 7, the authors developed a follow-up interview

\section{Socio-Demographic Questionnaire}

A questionnaire constructed for this study was used, which seeks to collect sociodemographic data about the caregiver and his/her family, such as age, gender, marital status, years of schooling and socioeconomic level, among others.

\section{Procedure}

During the study period, all primary caregivers of children aged 18-24 months were invited to participate in the study when they attended their routine child health check, explaining the scope and objectives of the study. To those who agreed to participate, a pediatric nurse gave them a folder with the following printed documents (i) sociodemographic questionnaire, (ii) Q-CHAT and (iii) M-CHAT-R/F. A second administration of Q-CHAT was performed on 24 participants, 3 weeks after the first administration, ensuring that the same conditions of the first administration were maintained: same caregiver and same location.

\section{Ethical Considerations}

By signing an informed consent, the free and voluntary participation, the confidentiality of the data provided by the participants and the fact that they would be used only for research purposes were assured. This research was approved by the ethics committee of Araucanía Health Service, Chile. Participants whose scores met the threshold criteria on the Q-CHAT ( $\geq 38$ ) and/or the MCHAT-R/F $(\geq 3)$ were contacted to invite them for a diagnostic evaluation by a specialized team. This assessment consisted of a semi-structured interview of the child's development and the application of the ADOS-2 T module. 


\section{Statistical analysis}

The analyses were performed using the Statistical Package for Social Sciences (SPSS), Version 25 for Mac; the FACTOR statistical package (47) version 10.10.01 and the JASP statistical software, version 0.11.1 (48). The distribution of total Q-CHAT score was explored using the Kolmogorov-Smirnov test $(K-S)$. The results were contrasted with the distribution histogram and the standardized normal distribution probability graph (Q-Q Plot). Q-CHAT total score was compared with the total score distributions reported in previous studies, using the Student's $t$ test for one sample and the total scores of boys and girls were contrasted, using Student`s $t$ test for independent two-samples. Item-total correlations were examinated using Pearson's r parametric analyses. Before performing the EFA, the goodness of fit of the data was analyzed for a factorial model, using the Kaiser Meyer-Olkim (KMO) and Bartlett's sphericity test which measure sampling adequacy. Since the conditions were satisfied, the factorial structure of Q-CHAT was explored using a polychoric correlation matrix, the Unweighted Least Squares (ULS) extraction method and the Promin rotation. To determine the number of factors to be retained, a Parallel Analysis (PA) was performed. As an estimate of the convergent validity of the test, a Pearson's r correlation was performed between the total score on the Q-CHAT and the M-

CHAT-R/F. Reliability was estimated by examining internal consistency using Cronbach's Alpha and the test-retest reliability by examining the intraclass correlation coefficient (ICC).

\section{Results}

\section{Q-CHAT total scores distribution, ítem score distribution and item analysis}

The mean score was 32.1 (range 6-63, SD=10.6). The Kolmogorov-Smirnov test revealed that scores was normally distributed $(K-S(188)=0.048, \mathrm{p}>0.01)($ Figs 1 and 2$)$. 
Figure 1. Histogram of Q-CHAT total scores distribution in the studied sample $(\mathbf{n}=188)$

Figure 2. Q-Q Plot for Q-CHAT total scores in the studied sample $(n=188)$

Q-CHAT total scores in this sample of Chilean children were significantly higher than those found in other community samples $(29,30)$. Table 2 compares Q-CHAT total scores with previous studies.

Table 2. Comparison of the distributions of Q-CHAT total scores in this study ${ }^{\dagger}$ with samples from previous studies

\begin{tabular}{|c|c|c|c|c|c|}
\hline$\frac{\text { Study (year) }}{\text { Country }}$ & $N$ & $\frac{\text { Q-CHAT Scores }}{M(S D)}$ & $\frac{\text { Student's } t \text { Test }}{T(\mathrm{gl})}$ & $p$ value & $\frac{\text { Effect size }}{\text { Cohen`s } d}$ \\
\hline $\begin{array}{c}\text { Allison (2008) } \\
\text { UK }\end{array}$ & 754 & $26.7(7.8)$ & $7.05(187)$ & $0.001 * *$ & 0.51 \\
\hline $\begin{array}{c}\text { Villablanca (2013) } \\
\text { Colombia }\end{array}$ & 231 & 33.4 (7) & $-1.64(231)$ & 0.101 & -0.12 \\
\hline $\begin{array}{c}\text { Wong (2014) } \\
\text { UK }\end{array}$ & 141 & $33.7(8.3)$ & $-2.03(187)$ & $0.043^{*}$ & -0.14 \\
\hline $\begin{array}{l}\text { Magiati (2015) } \\
{ }_{\text {\$Singapur }}\end{array}$ & $368^{\star}$ & $35.6(7.2)$ & $-4.49(187)$ & $0.001 * *$ & -0.32 \\
\hline $\begin{array}{l}\text { Magiati (2015) } \\
\text { II Singapur }\end{array}$ & $396^{*}$ & $33.2(7.7)$ & $-1.38(187)$ & 0.168 & -0.10 \\
\hline $\begin{array}{c}\text { Mohammadian (2015) } \\
\text { Siria }\end{array}$ & 100 & $22.4(6.26)$ & $12.63(187)$ & $0.001 * *$ & 0.92 \\
\hline $\begin{array}{c}\text { Modi (2019) } \\
\text { UK }\end{array}$ & 141 & $33.7(8.3)$ & $-2.03(187)$ & $0.043 *$ & -0.15 \\
\hline $\begin{array}{l}\text { Ruta (2019) } \\
\text { Italia }\end{array}$ & $2400^{\ddagger}$ & $25.8(7.8)$ & 8.21 (187) & $0.001 * *$ & 0.59 \\
\hline $\begin{array}{c}\text { Ruta (2019) } \\
\text { Italia }\end{array}$ & 126 & $21.1(6.7)$ & $14.31(187)$ & $0.001 * *$ & 1.044 \\
\hline
\end{tabular}

${ }^{\dagger} \mathrm{Q}-\mathrm{CHAT}$ total scores in this study: $\mathrm{M}=32.13, \mathrm{SD}=10.56$, Range 6-63.

${ }^{\ddagger} \mathrm{N}$ corresponding to community sample. ${ }^{\S} 18$-month sub-sample; ${ }^{\sharp} 24$-month sub-sample. ${ }^{*} p<0.05 ; * * \mathrm{p}<0.001$

The two community samples with which our sample has significant differences in Q-CHAT Scores are highlighted in grey.

The mean scores for boys of 33.6 ( $S D=10.9$, range 8 -59) was significantly higher than the mean score for girls of $30.4(\mathrm{SD}=9.9$, range $6-63)(\mathrm{t}(186)=2.15, \mathrm{p}<0.05$, equal variances assumed $)$, with a small effect size $(\mathrm{d}=0.34)$. The distribution of scores on each of the items (expressed as percentages) are shown in Table 3. 
Table 3. Item score distribution (\%)

\begin{tabular}{|c|c|c|c|c|c|}
\hline \multirow[t]{2}{*}{ Items Q-CHAT } & \multicolumn{5}{|c|}{ Scores $(\%)$} \\
\hline & 0 & 1 & 2 & 3 & 4 \\
\hline 1. Looks when called by name & 70.2 & 16.4 & 8.5 & 4.3 & 0.5 \\
\hline 2. Eye contact & 65.4 & 27.7 & 6.4 & 0.5 & 0.0 \\
\hline 3. Lines objects up ${ }^{\dagger}$ & 13.3 & 17 & 41 & 16.5 & 12.2 \\
\hline 4. Understands child's speech & 19.7 & 19.7 & 33.5 & 14.3 & 12.8 \\
\hline 5. Protoimperative pointing & 70.7 & 19.2 & 4.3 & 0.5 & 5.3 \\
\hline 6. Protodeclarative pointing & 70.7 & 15.5 & 6.4 & 2.6 & 4.8 \\
\hline 7. Interest maintained by spinning object ${ }^{\dagger}$ & 47.3 & 44.2 & 4.3 & 2.1 & 2.1 \\
\hline 8. Number of words ${ }^{\dagger}$ & 2.1 & 5.8 & 37.2 & 49 & 6 \\
\hline 9. Pretend play & 59 & 23.9 & 5.9 & 5.3 & 5.9 \\
\hline 10. Follow a look & 45.7 & 38.3 & 10.6 & 2.7 & 2.7 \\
\hline 11. Sniff/lick unusual objects ${ }^{\dagger}$ & 22.3 & 10.1 & 15.4 & 30.9 & 21.3 \\
\hline 12. Use of hand as tool ${ }^{\dagger}$ & 6.4 & 4.3 & 8.5 & 28.7 & 52.1 \\
\hline 13. Walk on tiptoes ${ }^{\dagger}$ & 32.5 & 23.4 & 25 & 13.8 & 5.3 \\
\hline 14. Adapt to change in routine & 41.5 & 48.9 & 5.9 & 3.7 & 0.0 \\
\hline 15. Offer comfort & 48.9 & 24.5 & 15.4 & 6.4 & 4.8 \\
\hline 16. Do same thing over and over again ${ }^{\dagger}$ & 9.6 & 5.8 & 15.4 & 26.1 & 43.1 \\
\hline 17. Typicality of first words & 40.4 & 48.4 & 2.7 & 1.1 & 7.4 \\
\hline 18. Echolalia $^{\dagger}$ & 27.1 & 5.3 & 16 & 29.8 & 21.8 \\
\hline 19. Gestures & 78.2 & 15.4 & 1.6 & 2.1 & 2.7 \\
\hline 20. Unusual finger movements ${ }^{\dagger}$ & 44.7 & 13.8 & 16 & 17 & 8.5 \\
\hline 21. Check reaction & 45.2 & 20.7 & 22.9 & 8.5 & 2.7 \\
\hline 22. Maintenance of interest ${ }^{\dagger}$ & 49.5 & 25 & 14.9 & 5.8 & 4.8 \\
\hline 23. Twiddle objects repetitively ${ }^{\dagger}$ & 31.4 & 16 & 13.8 & 21.8 & 17 \\
\hline 24. Oversensitive to noise ${ }^{\dagger}$ & 37.8 & 27.7 & 18 & 8.5 & 8 \\
\hline 25. Stare at nothing with no purpose ${ }^{\dagger}$ & 55.3 & 21.3 & 9.1 & 12.2 & 2.1 \\
\hline
\end{tabular}

'Reverse-scored items.

All items (except item 18), were positively correlated with Q-CHAT total score. The item-total correlation was satisfactory $(0.5>r>0.2)$ for most items, except for items 3,12 and $21(r<0.2)$. Item 18 ("echolalia") showed a negative correlation with the rest of the test $(r=-0.01)$. Table 4 summarizes the item-total correlations.

Table 4. Rational analysis of the items: Item-total Q-CHAT Correlation

\begin{tabular}{|c|c|}
\hline \multirow[t]{2}{*}{ Items } & Item-total correlation \\
\hline & (Pearson`s $r)$ \\
\hline 6. Protodeclarative pointing & $0.414^{\dagger}$ \\
\hline 25. Stare at nothing with no purpose ${ }^{\dagger}$ & $0.403^{\dagger}$ \\
\hline 11. Sniff/lick unusual objects ${ }^{\dagger}$ & $0.394^{\dagger}$ \\
\hline 4. Understand child's speech & $0.388^{\dagger}$ \\
\hline 1. Looks when called by name & $0.382^{\dagger}$ \\
\hline 8. Number of words ${ }^{\dagger}$ & $0.376^{\dagger}$ \\
\hline 2. Eye contact & $0.372^{\dagger}$ \\
\hline
\end{tabular}


20. Unusual finger movements

$0.363^{\dagger}$

23. Twiddle objects repetitively ${ }^{\dagger}$

$0.355^{\dagger}$

5. Protoimperative pointing

$0.338^{\dagger}$

19. Gestures

$0.329^{\dagger}$

10. Follow a look

$0.319^{\dagger}$

16. Does same thing over and over again ${ }^{\dagger}$

$0.318^{\dagger}$

15. Offers comfort

$0.313^{\dagger}$

24. Oversensitive to noise ${ }^{\dagger}$

$0.305^{\dagger}$

14. Adapts to change(s) in routine $0.290^{\dagger}$

17. Typicality of first words $0.250^{\dagger}$

9. Pretend play $0.235^{\dagger}$

22. Maintenance of interest ${ }^{\dagger} \quad 0.231^{\dagger}$

7. Interest maintained by spinning object ${ }^{\dagger} \quad 0.230^{\dagger}$

13. Walks on tiptoes ${ }^{\dagger}$

12. Use of hand as tool ${ }^{\dagger} \quad 0.195$

3. Lines objects up ${ }^{\dagger} \quad 0.144$

21. Checks reaction $\quad 0.057$

18. Echolalia ${ }^{\dagger} \quad-0.010$

Reverse-scored items.

$\$$ Satisfactory correlation $(0.5>\mathrm{r}>0.2)$

\section{Evidence of validity, Q-CHAT exploratory factor analysis (EFA)}

Based on the analysis of the items, a factorial structure was explored excluding item 18 ("echolalia"), since it presented a negative item-total correlation ( $r=-0.01)$. The sample adequacy measure for EFA was satisfactory $(K M O=0.81)$ and Bartlett's sphericity test was statistically significant $\left(X^{2}(276)=1352.9, p<0.0001\right)$. The Parallel Analysis suggested retaining two factors, which explain $42.2 \%$ of the variance (factor 1, 25.4\%; factor 2, 16.8\%). The goodness-of-fit index for this factor structure was acceptable $(G F I=0.96)$. Factor 1 comprises 11 items $(3,7,11$, $12,13,16,20,22,23,24$ and 25) related to repetitive and restrictive behaviors, and is therefore called "Restrictive and Repetitive Patterns". Factor 2 includes 13 items (1, 2, 4, 5, 6, 8, 9, 10, 14, 15, 17, 19 and 21) related to socio-communicative difficulties and was named "Communication and Social Interaction". The correlation between Factor 1 and Factor 2 was low with a small effect size $(r=-0.12)$. The factorial structure obtained through EFA is summarized in Table 5. 
Table 5. Factorial structure of Q-CHAT obtained through Exploratory Factor Analysis a

\begin{tabular}{|c|c|c|}
\hline \multirow[t]{2}{*}{ Item } & Factor 1 & Factor 2 \\
\hline & $\begin{array}{c}\text { Restrictive and } \\
\text { Repetitive Patterns }\end{array}$ & $\begin{array}{l}\text { Communication anc } \\
\text { Social Interaction }\end{array}$ \\
\hline 3. Lines objects up ${ }^{\dagger}$ & 0.455 & \\
\hline 7. Interest maintained by spinning object ${ }^{\dagger}$ & 0.473 & \\
\hline 11. Sniff/lick unusual objects ${ }^{\dagger}$ & 0.516 & \\
\hline 12. Uses of hand as tool ${ }^{\dagger}$ & 0.501 & \\
\hline 13. Walks on tiptoes ${ }^{\dagger}$ & 0.498 & \\
\hline 16. Does same thing over and over again ${ }^{\dagger}$ & 0.698 & \\
\hline 20. Unusual finger movements ${ }^{\dagger}$ & 0.716 & \\
\hline 22. Maintenance of interest ${ }^{\dagger}$ & 0.419 & \\
\hline 23. Twiddle objects repetitively ${ }^{\dagger}$ & 0.726 & \\
\hline 24. Oversensitive to noise ${ }^{\dagger}$ & 0.317 & \\
\hline 25. Stares at nothing with no purpose $e^{\dagger}$ & 0.453 & \\
\hline 1. Looks when called by name & & 0.750 \\
\hline 2. Eye contact & & 0.638 \\
\hline 4. Understands child's speech & & 0.637 \\
\hline 5. Protoimperative pointing & & 0.683 \\
\hline 6. Protodeclarative pointing & & 0.861 \\
\hline 8. Number of words ${ }^{\dagger}$ & & 0.595 \\
\hline 9. Pretend play & & 0.586 \\
\hline 10. Follow a look & & 0.638 \\
\hline 14. Adapts to change in routine & & 0.301 \\
\hline 15. Offers comfort & & 0.625 \\
\hline 17. Typicality of first words & & 0.363 \\
\hline 19. Gestures & & 0.717 \\
\hline 21. Check reaction & & 0.406 \\
\hline
\end{tabular}

${ }^{\dagger}$ Reverse-scored items.

¥Factor extraction method: Unweighted Least Squares (ULS); Procedure for determining number of dimensions: Parallel Analysis (PA); Rotation to achieve factor simplicity: Promin.

\section{Evidence of convergent validity of Q-CHAT with M-CHAT-R/F}

Q-CHAT total scores in the sample studied correlated positively and significantly with the MCHAT-R/F scores $(r=0.59, p<0.01)$, with a large effect size. All items corresponding to factor 2 "Communication and Social Interaction" correlated significantly with M-CHAT-R/F scores, with a large effect size $(r>0.5, p<0.001)$ for items $1,2,5,6,10$ and 19, and with a moderate effect size $(0.5>r>0.3)$ for items $4,9,8,15,17$ and 21 . In contrast, only 3 items (18, 25 and 24) corresponding to factor 1 "Restrictive and Repetitive Patterns" correlated significantly with MCHAT-R/F scores. Table 6 summarizes these findings. 
Table 6. Correlation between Q-CHAT items and M-CHAT/RF total score

\begin{tabular}{|c|c|}
\hline Ítems & Pearson's $r$ \\
\hline 1. Look when call name & $0.706 * *$ \\
\hline 6. Protodeclarative pointing & $0.689 * *$ \\
\hline 2. Eye contact & $0.579 * *$ \\
\hline 5. Protoimperative pointing & $0.549 * *$ \\
\hline 19. Gestures & $0.504 * *$ \\
\hline 10. Follow a look & $0.503^{* *}$ \\
\hline 15. Offer comfort & $0.470^{* *}$ \\
\hline 9. Pretend play & $0.447 * *$ \\
\hline 4. Understand child's speech & $0.396^{* *}$ \\
\hline 8. Number of words ${ }^{\dagger}$ & $0.373 * *$ \\
\hline 17. Typicality of first words & $0.303 * *$ \\
\hline 21. Check reaction & $0.301 * *$ \\
\hline 18. Echolalia* ${ }^{*}$ & $-0.256 * *$ \\
\hline 25. Stare at nothing with no purpose ${ }^{\dagger}$ & $0.209^{*}$ \\
\hline 24. Oversensitive to noise ${ }^{\dagger}$ & $0.206^{*}$ \\
\hline 14. Adapt to change in routine & 0.141 \\
\hline 11. Sniff/lick unusual objects ${ }^{\dagger}$ & 0.127 \\
\hline 20. Unusual finger movements ${ }^{\dagger}$ & 0.110 \\
\hline 3. Line objects up ${ }^{\dagger}$ & -0.052 \\
\hline 13. Walk on tiptoes ${ }^{\dagger}$ & -0.035 \\
\hline 23. Twiddle objects repetitively ${ }^{\dagger}$ & 0.033 \\
\hline 7. Interest maintained by spinning object ${ }^{\dagger}$ & 0.026 \\
\hline 22. Maintenance of interest ${ }^{\dagger}$ & 0.019 \\
\hline 12. Use of hand as tool ${ }^{\dagger}$ & 0.009 \\
\hline 16. Do same thing over and over again ${ }^{\dagger}$ & 0.004 \\
\hline
\end{tabular}

'Reverse-scored items.

$* p<0.01 ; * * p<0.001$

\section{Q-CHAT reliability}

Internal consistency was acceptable for the full scale (Cronbach's $\alpha=0.74$ ). The internal consistencies of the resulting factors of the EFA were analyzed, being acceptable for factor 1 (Cronbach's $\alpha=0.77$ ) and good for the factor 2 (Cronbach's $\alpha=0.86$ ). Regarding test-retest reliability, 24 participants (12.8\% of the sample) agreed to complete the Q-CHAT for a second time, three weeks after the first administration. The total Q-CHAT score for the first administration $(M=29.79, S D=13.93)$ and the second administration $(M=25.08, S D=10.24)$ differed from each other. Student's $t$ test for related samples showed that these differences were significant $(t(23)=3.61, p<0.01)$. However, the intraclass correlation coefficient (ICC) (which 
measures test-retest reliability across the whole measure) was good $(I C C=0.86, p<0.001)$, according to the criteria proposed by Koo \& Li (49).

\section{Discussion}

The aim of this study was to study the psychometric properties of the Q-CHAT (culturally adapted to Chile) in the context of a pilot program for early detection of autism in a unselected children group (community sample) aged 18-24 months.

Q-CHAT total score showed a normal distribution, replicating previous findings and in other cultural contexts, both in community sample (29-31) and groups with an increased likelihood of autism $(33,36)$, and confirms the quantitative and dimensional nature with which Q-CHAT was conceived (30). From a practical point of view, the dimensional approach allows overcoming the potential limitation of the categorical approach: identifying the most obvious autistic children and under-detecting the least obvious cases (29). From another point of view, the observed distributions are consistent with the theoretical hypothesis that conceptualizes autism as a construct of clinical manifestations and traits that are normally distributed in the general population (among individuals) and within the "autism spectrum" (in individuals) $(32,50)$.

The distribution of total Q-CHAT scores in this community sample of Chilean children was significantly higher than reported in community samples of British (30) and Italian children (29) and significantly lower than reported in a community sample of Singaporean children (31). Cultural differences may partly explain the higher Q-CHAT scores in Chilean child population compared to European and U.S. children, just as differences between Asian and European populations have been explained by Magiati et al. (31). These differences can also be seen when comparing studies that have used other tools to measure autistic traits in Chilean children. For example, mean scores of M-CHAT-R/F $(M=0.81, \mathrm{SD}=-1.21)$ in a sample of Chilean children (46) 
were significantly higher than those reported in a sample of U.S. children (28) with a small difference in effect size $(\mathrm{M}=0.4, \mathrm{SD}=0.27$; calculated $\mathrm{d}=-0.37)$.

On the other hand, since $29.3 \%(n=55)$ of the participants scored above the autism risk cut-off point (>37), it is possible that the higher Q-CHAT scores in our sample can be explained by an over-representation of primary caregivers who participated motivated by autism-related concerns (self-selection bias).

As reported by $(29,30,34)$, we found significantly higher scores for boys than for girls. These results are consistent with epidemiological and genetic evidence showing that males are associated with higher autistic traits in general population samples (51-53).

The rational analysis of the Q-CHAT items showed that 21 of the 25 items present item-total correlations with satisfactory values. Item 18 ("echolalia") negatively correlates with Q-CHAT total score. Since echolalia is a phenomenon present in early development and not specific to autism (54), it is possible that caregivers consider echolalia as a normative phenomenon of early language development.

The EFA revealed a two-dimensional structure which is in contrast to what has previously been reported in other factor structure studies of the Q-CHAT $(29,31)$. We opted for Parallel Analysis (PA) to determine the number of factors to be retained in the model, which Ledesma \& Valero-Mora (55) suggest is the most accurate procedure for factor retention. The Kaiser's criterion tends to overestimate the number of factors and the Scree Plot is not optimal because of its subjective nature for determining the number of factors to retain (56).

Factor 1 (11 items) relates to repetitive and/or stereotypical behaviors (3."Line objects up," 13."Walk on tiptoes", 16."Do same thing over and over again", 20."Unusual finger movements", 23."Twiddle objects repetitively" and 25.'Looks with no apparent purpose"), restricted interests (7."Interest maintained by spinning object", 11."Sniff/lick unusual objects", 22."Maintenance of 
interest"), sensory hyperreactivity (24."Oversensitive to noise"), and instrumentalization (12."Use of hand as tool"). There is phenomenological agreement of the statements with criterion B of DSM-5 (1), which allows this factor to be called "Restrictive and Repetitive Patterns". Even though all the items grouped in this factor have a theoretical concordance with the dimension of non-social behaviors, item 12 ("Use of hand as tool") could be an exception, since this behavior has been considered to refer primarily to a sociocommunicative deficit in autism (57). We agree with Ruta, Arduino, et al. (29) that it is likely that in the process of responding to the item, parents have interpreted this phenomenon as a normative developmental behavior of the child. Along these lines, Gómez (58), criticizes the historical association that has been made between the behavior of using the hand of another and the qualitative deterioration of social interaction in autism, stating that the use of the "hand as a tool" is a behavior that is present even in neurotypical development.

Factor 2 groups 13 items that allude to the occurrence of deficiencies in verbal and non-verbal communication (4."Understand child's speech", 8."Number of words", 17."Typicality of first words"), deficits in eye contact (1."Look when call name", 2."Eye contact"), deficits in joint attention and social reference (10."Follow a look", 21."Check reaction"), social reciprocity (15."Offer comfort"), deficiencies in the use of conventional gestures and pointing (5."Protoimperative pointing", 6."Protodeclarative pointing", 19."Gestures"), symbolic play (9."Pretend play") and adaptation to changes (14."Adapt to change in routine"). Based on criterion A of DSM-5 (1), this factor was called "Communication and Social Interaction".

The correlation between Factor 1 and Factor 2 was very weak and with a small effect size ( $r=-$ 0.12). This is consistent with Mandy \& Skuse (59). In a review of the factorial models of autism they found that in the models studied the socio-communicative and non-social elements are independent dimensions and with a correlation that can tend towards zero. The 2-factor structure 
meets the requirement of being at the same time interpretable, simplified, parsimonious and theoretically justified $(60,61)$.

The correlation between Q-CHAT and M-CHAT/R-F was positive, significant and with a large effect size, which provides evidence that the Q-CHAT has convergent validity, and that both instruments measure the same construct. Interestingly, when analyzing the correlations of individual Q-CHAT items with the total score on M-CHAT/R-F, all items of factor 2 "Communication and Social Interaction" (except item 14 "Adaptation to changes in routine"), showed significant correlations and with large or moderate effect size. In contrast, only 2 items from factor 1 "Restrictive and Repetitive Patterns" (24. "Hypersensitive to noise" and 25. "Stare at nothing with no purpose") showed significant correlations with M-CHAT/R-F scores.

Reliability analysis show acceptable values for the overall scale and for factor 1, and good for factor 2. Test-retest reliability, as measured by the intraclass correlation coefficient, is considered good. A significant decrease was observed between the total Q-CHAT score at the first and second administration. This decrease is possibly because parents are more aware of their children's behaviors after the first administration.

\section{Limitations}

These preliminary results suggest that need to further explore the performance of the Q-CHAT in a Chilean population. The limitations of this study are primarily related to the sample size. Although the ratio of observations per item (7.5:1) is within the acceptable margins for conducting an EFA, it does not reach the 10:1 ratio considered optimal (62). Although some authors do not agree with these ratios a priori, they all agree that the size of the sample determines the quality of the conclusions and the methods to be used in the EFA (56). Similarly, the variability in the factor structure reported for the Q-CHAT in previous research supported the need to initially perform an EFA, and not seek to replicate the factor structures reported by other 
research teams through a Confirmatory Factor Analysis. Evidence for test accuracy of the QCHAT is a pending task for the follow-up study. This will be reported in a future study, using the Autism Diagnostic Observation Schedule, ADOS-2 (63) as a diagnostic instrument to confirm outcome.

\section{Conclusions}

In accordance with the aim of examining the psychometric properties of a culturally adapted version of Q-CHAT in Chile, this study showed a two-factor structure through EFA, which is phenomenologically concordant with the dimensional criteria of autism in the DSM-5. In the same way, evidence of convergent validity with the M-CHAT-R/F and evidence of reliability through internal consistency and retest have been obtained. The results of this research are encouraging in terms of its use as an early detection tool, which also quantifies autistic traits dimensionally.

Future directions following this preliminary study include examining the Q-CHAT as an early detection measure for autism in larger samples and to carry out follow-up studies to obtain evidence of its predictive validity in the Chilean child population. Similarly, it will be useful to incorporate other developmental variables such as measures of language and social development in future studies which will allow for determining convergent and discriminant validity.

Finally, the finding that there are significant differences in total Q-CHAT score across different cultures poses the challenge of using other methodological designs to assess equivalence and test structure across different cultures. 


\section{Declarations}

\section{Acknowledgements}

We would like to thank Susana Román and Virginia Monroy C, from the Children's Health and Rural Health Equity Program of the Southern Araucanía Health Service, for their logistical contribution to this research. We thank the Tremün Foundation for its contribution to the child development of the children in our territory.

\section{Ethics approval}

Permission to conduct this study was obtained from the Scientific Ethics Committee of the Araucanía Sur Health Service, Chile (FOLIO No. 00000230). The informed consent of all participants has been obtained.

\section{Data Availability Statement}

The data sets generated and analyzed during this study are not publicly available because of our agreement with the parents of the children. However, they can be obtained from the author upon reasonable request.

\section{Competing interests}

The authors have declared that they have no competing or potential conflicts of interest.

\section{Funding}

This research has not received funding from public or private institutions. 


\section{References}

1. American Psychiatric Association. Diagnostic and Statistical Manual of Mental Disorders. 5th edn. 5 th. Arlington, VA: American Psychiatric Publishing; 2013. 50-51 p.

2. Baio J, Wiggins L, Christensen DL, Maenner MJ, Daniels J, Warren Z, et al. Prevalence of autism spectrum disorder among children aged 8 Years - Autism and developmental disabilities monitoring network, 11 Sites, United States, 2014. MMWR Surveill Summ. 2018;67(6):1-23. doi.org/10.15585/mmwr.ss6706a1.

3. MINSAL. Guía de Practica Clínica de Detección y Diagnóstico Oportuno de los Trastornos del Espectro Autista (TEA) [Internet]. Departamento de Discapacidad y Rehabilitación, Ministerio de Salud de Chile, Ministerio de Salud de Chile. 2011. Available from: https://www.minsal.cl/portal/url/item/bd81e3a09ab6c3cee040010164012ac2.pdf

4. Elder JH, Kreider CM, Brasher SN, Ansell M. Clinical impact of early diagnosis of autism on the prognosis and parent-child relationships. Psychol Res Behav Manag. 2017; 10:1-9. doi.org/10.2147/PRBM.S117499.

5. Dawson G, Rogers S, Munson J, Smith M, Winter J, Greenson J, et al. Randomized, Controlled Trial of an Intervention for Toddlers with Autism: The Early Start Denver Model. Pediatrics. 2010;125(1): e17-23. doi.org/10.1542/peds.2009-0958.

6. Zwaigenbaum L, Bauman ML, Choueiri R, Kasari C, Carter A, Granpeesheh D, et al. Early Intervention for Children with Autism Spectrum Disorder Under 3 Years of Age: Recommendations for Practice and Research. Pediatrics. 2015;136(1): s60-81. doi.org/10.1542/peds.2014-3667E.

7. Rogers SJ, Vismara L, Wagner AL, McCormick C, Young G, Ozonoff S. Autism Treatment in the First Year of Life: A Pilot Study of Infant Start, a Parent-Implemented Intervention for 
Symptomatic Infants. J Autism Dev Disord. 2014;44(12):2981-95. doi.org/10.1007/s10803014-2202-y.

8. Mandell DS, Novak MM, Zubritsky CD. Factors associated with age of diagnosis among children with autism spectrum disorders. Pediatrics. 2005;116(6):1480-6. doi.org/10.1542/peds.2005-0185.

9. Zwaigenbaum L, Bryson S, Garon N. Early identification of autism spectrum disorders. Behav Brain Res [Internet]. 2013; 251:133-46. doi.org/10.1016/j.bbr.2013.04.004.

10. Sheldrick RC, Maye MP, Carter AS. Age at First Identification of Autism Spectrum Disorder: An Analysis of Two US Surveys. J Am Acad Child Adolesc Psychiatry [Internet]. 2017;56(4):313-20. doi.org/10.1016/j.jaac.2017.01.012.

11. Deconinck N, Soncarrieu M, Dan B. Toward better recognition of early predictors for autism spectrum disorders. Pediatr Neurol [Internet]. 2013;49(4):225-31. doi.org/10.1016/j.pediatrneurol.2013.05.012.

12. Ozonoff S, Young GS, Belding A, Hill M, Hill A, Hutman T, et al. The broader autism phenotype in infancy: When does it emerge? J Am Acad Child Adolesc Psychiatry [Internet]. 2014;53(4):398-407e2. doi.org/10.1016/j.jaac.2013.12.020.

13. Chawarska K, Macari S, Shic F. Decreased spontaneous attention to social scenes in 6month-old infants later diagnosed with autism spectrum disorders. Biol Psychiatry. 2013;74(3):195-203. doi.org/10.1016/j.biopsych.2012.11.022.

14. Allison C, Auyeung B, Baron-Cohen S. Toward brief "Red Flags" for Autism Screening: The short Autism Spectrum Quotient and the short Quantitative Checklist in 1,000 Cases and 3,000 Controls. J Am Acad Child Adolesc Psychiatry [Internet]. 2012;51(2):202-212.e7. doi.org/10.1016/j.jaac.2011.11.003. 
15. Barbaro J, Dissanayake C. Early markers of autism spectrum disorders in infants and toddlers prospectively identified in the Social Attention and Communication Study. Autism. 2012;17(1):64-86. doi.org/10.1177/1362361312442597.

16. Chawarska K, Shic F, Macari S, Campbell DJ, Brian J, Landa R, et al. 18-month predictors of later outcomes in Younger siblings of children with autism spectrum disorder: A baby siblings research consortium study. J Am Acad Child Adolesc Psychiatry [Internet]. 2014;53(12):1317-1327.e1. doi.org/10.1016/j.jaac.2014.09.015.

17. Korkmaz B. Theory of mind and neurodevelopmental disorders of childhood. Pediatr Res. 2011;69(5). doi.org/10.1203/PDR.0b013e318212c177.

18. Lai M-C, Lombardo M V., Baron-Cohen S. Autism. Lancet. 2014;383(9920):896-910. doi.org/10.1016/S0140-6736(13)61539-1.

19. Mukherjee SB. Autism Spectrum Disorders — Diagnosis and Management. Indian J Pediatr [Internet]. 2017;84(4):307-14. doi.org/10.1007/s12098-016-2272-2.

20. Zwaigenbaum L, Bryson S, Lord C, Rogers S, Carter A, Carver L, et al. Clinical assessment and management of toddlers with suspected autism spectrum disorder: Insights from studies of high-risk infants. Pediatrics. 2009;123(5):1383-91. doi.org/10.1542/peds.2008-1606.

21. Nickel RE, Huang-Storms L. Early Identification of Young Children with Autism Spectrum Disorder. Indian J Pediatr. 2017;84(1):53-60. doi.org/10.1007/s12098-015-1894-0.

22. Johnson CP, Myers SM. Identification and evaluation of children with autism spectrum disorders. Pediatrics. 2007;120(5):1183-215. doi.org/10.1542/peds.2007-2361.

23. Zwaigenbaum L, Bauman ML, Fein D, Pierce K, Buie T, Davis PA, et al. Early screening of autism spectrum disorder: Recommendations for practice and research. Pediatrics. 2015;136(S1): S41-59. doi.org/10.1542/peds.2014-3667D. 
24. McPheeters ML, Weitlauf A, Vehorn A, Taylor C, Sathe NA, Krishnaswami S, et al. Screening for Autism Spectrum Disorder in Young Children: A Systematic Evidence Review for the U.S. Preventive Services Task Force [Internet]. AHRQ Publication No. 13-05185-EF1. 2016. Available from:

http://www.ncbi.nlm.nih.gov/pubmed/26985520\%5Cnhttp://www.uspreventiveservicestaskfo rce.org/Page/Document/draft-evidence-review106/autism-spectrum-disorder-in-youngchildren-screening

25. Bejarano-Martín Á, Canal-Bedia R, Magán-Maganto M, Fernández-Álvarez C, CillerosMartín MV, Sánchez-Gómez MC, et al. Early Detection, Diagnosis and Intervention Services for Young Children with Autism Spectrum Disorder in the European Union (ASDEU): Family and Professional Perspectives. J Autism Dev Disord [Internet]. 2020;50(9):3380-94. doi.org/10.1007/s10803-019-04253-0.

26. Baron-Cohen S, Allen J, Gillberg C. Can Autism be Detected at 18 Months? The needle, the haystack, and the CHAT. Br J Psychiatry. 1992;161(6):839-43. doi.org/10.1192/bjp.161.6.839.

27. Robins DL, Fein D, Barton ML, Green JA. The Modified Checklist for Autism in Toddlers: An Initial Study Investigating the Early Detection of Autism and Pervasive Developmental Disorders. J Autism Dev Disord. 2001;31(2):131-44. doi.org/10.1023/A:1010738829569.

28. Robins DL, Casagrande K, Barton M, Chen CMA, Dumont-Mathieu T, Fein D. Validation of the modified checklist for autism in toddlers, revised with follow-up (M-CHAT-R/F). Pediatrics. 2014;133(1):37-45. doi.org/10.1542/peds.2013-1813.

29. Ruta L, Arduino GM, Gagliano A, Apicella F, Leonardi E, Famà FI, et al. Psychometric properties, factor structure and cross-cultural validity of the quantitative CHecklist for autism 
in toddlers (Q-CHAT) in an Italian community setting. Res Autism Spectr Disord [Internet]. 2019; 64:39-48. doi.org/10.1016/j.rasd.2019.04.004.

30. Allison C, Baron-Cohen S, Wheelwright S, Charman T, Richler J, Pasco G, et al. The QCHAT (Quantitative CHecklist for Autism in Toddlers): A normally distributed quantitative measure of autistic traits at 18-24 months of age: Preliminary report. J Autism Dev Disord. 2008;38(8):1414-25. doi.org/10.1007/s10803-007-0509-7,

31. Magiati I, Goh DA, Lim SJ, Gan DZQ, Leong JCL, Allison C, et al. The psychometric properties of the Quantitative-Checklist for Autism in Toddlers (Q-CHAT) as a measure of autistic traits in a community sample of Singaporean infants and toddlers. Mol Autism [Internet]. 2015;6(1):40-53. doi.org/10.1186/s13229-015-0032-1.

32. Constantino JN, Charman T. Diagnosis of autism spectrum disorder: reconciling the syndrome, its diverse origins, and variation in expression. Lancet Neurol [Internet]. 2016;15(3):279-91. doi.org/10.1016/S1474-4422(15)00151-9.

33. Modi N, Ashby D, Battersby C, Brocklehurst P, Chivers Z, Costeloe K, et al. Developing routinely recorded clinical data from electronic patient records as a national resource to improve neonatal health care: The Medicines for Neonates research programme. Program Grants Appl Res. 2019;7(6):1-396. doi.org/10.3310/pgfar07060.

34. Mohammadian M, Zarafshan H, Mohammadi MR, Karimi I. Evaluating reliability and predictive validity of the Persian translation of quantitative checklist for autism in toddlers (Q-CHAT). Iran J Psychiatry. 2015;10(1):64-70.

35. Ruta L, Chiarotti F, Arduino GM, Apicella F, Leonardi E, Maggio R, et al. Validation of the Quantitative CHecklist for Autism in Toddlers (Q-CHAT) in an Italian clinical sample of young children with Autism and Other Developmental Disorders. Front Psychiatry. 2019; 10:488. doi.org/10.3389/fpsyt.2019.00488. 
36. Wong HS, Huertas-Ceballos A, Cowan FM, Modi N. Evaluation of Early Childhood SocialCommunication Difficulties in Children Born Preterm Using the Quantitative Checklist for Autism in Toddlers. J Pediatr. 2014;164(1):26-33e1. doi.org/10.1016/j.jpeds.2013.07.013.

37. Villalba J. Validación del Q-CHAT para Detectar el Trastorno Autista en Edades Tempranas [Internet]. Universidad Nacional de Colombia; 2013. Available from: http://www.bdigital.unal.edu.co/44819/1/80039340.2013.pdf

38. Raza S, Zwaigenbaum L, Sacrey L-AR, Bryson S, Brian J, Smith IM, et al. Brief Report: Evaluation of the Short Quantitative Checklist for Autism in Toddlers (Q-CHAT-10) as a Brief Screen for Autism Spectrum Disorder in a High-Risk Sibling Cohort. J Autism Dev Disord [Internet]. 2019;49(5):2210-8. doi.org/10.1007/s10803-019-03897-2.

39. Roman-Urrestarazu A, Yáñez C, López-Garí C, Elgueta C, Allison C, Brayne C, et al. Autism screening and conditional cash transfers in Chile: Using the Quantitative Checklist (QCHAT) for early autism detection in a low resource setting. Autism. 2020; 1362361320972277. doi:10.1177/1362361320972277.

40. GFK/ADIMARK. Nuevos Grupos Socioeconómicos 2018 [Internet]. 2018. Available from: http://www.aimchile.cl/wp-content/uploads/Nuevos-Grupos-Socioeconómicos-AIM-febrero2018-FINAL-2.pdf

41. RELAF, UNICEF. Cuidado de Niños Pequeños. Modelo para la Prevención del Abandono y la Institucionalización [Internet]. 2015. Available from: https://www.unicef.org/lac/20160907_UNICEF_RELAF_Prevencion.PDF

42. Elosua P, Mujika J, Almeida LS, Hermosilla D. Procedimientos analítico-racionales en la adaptación de tests. Adaptación al español de la batería de pruebas de razonamiento. Rev Latinoam Psicol. 2014;46(2):117-26. doi.org/10.1016/s0120-0534(14)70015-9. 
43. Pérez-Luco R, Lagos L, Mardones R, Sáez F. Taxonomía de diseños y muestreo en investigación cualitativa. Un intento de síntesis entre las aproximaciones teórica y emergente. Ambitos Rev Int Comun. 2018;39.

44. Ericsson KA, Simon HA. Verbal reports as data. Psychol Rev. 1980;87(3):215-51. doi.org/10.1037/0033-295X.87.3.215.

45. Gordillo Alfonso A, Flórez M del P. Los niveles de comprensión lectora: hacia una enunciación investigativa y reflexiva para mejorar la comprensión lectora en estudiantes universitarios. Actual Pedagógicas. 2009;1(53):95-107. doi.org/10.19052/ap.1048.

46. Coelho-Medeiros ME, Bronstein J, Aedo K, Pereira JA, Arraño V, Perez CA, et al. Validación del M-CHAT-R/F como instrumento de tamizaje para detección precoz en niños con trastorno del espectro autista. Rev Chil Pediatr. 2019;90(5):492-9. doi.org/10.32641/rchped.v90i5.703.

47. Lorenzo-Seva U, Ferrando PJ. FACTOR 9.2: A Comprehensive Program for Fitting Exploratory and Semiconfirmatory Factor Analysis and IRT Models. Appl Psychol Meas. 2013;37(6):497-8. doi.org/10.1177/0146621613487794.

48. JASP Team. JASP (Version 0.12.2)[Computer software] [Internet]. 2020. Available from: https://jasp-stats.org/

49. Koo TK, Li MY. A Guideline of Selecting and Reporting Intraclass Correlation Coefficients for Reliability Research. J Chiropr Med [Internet]. 2016;15(2):155-63. doi.org/10.1016/j.jcm.2016.02.012.

50. Lombardo M V., Lai M-C, Baron-Cohen S. Big data approaches to decomposing heterogeneity across the autism spectrum. Mol Psychiatry [Internet]. 2019;24(10):1435-50. doi.org/10.1038/s41380-018-0321-0. 
51. Baron-Cohen S, Wheelwright S, Skinner R, Martin J, Clubley E. The Autism-Spectrum Quotient (AQ): Evidence from Asperger Syndrome/High-Functioning Autism, Males and Females, Scientists and Mathematicians. J Autism Dev Disord. 2001;31(1):5-17. doi.org/10.1038/s41380-018-0321-0.

52. Chakrabarti B, Dudbridge F, Kent L, Wheelwright S, Hill-Cawthorne G, Allison C, et al. Genes related to sex steroids, neural growth, and social-emotional behavior are associated with autistic traits, empathy, and Asperger syndrome. Autism Res. 2009;2(3):157-77. doi.org/10.1002/aur.80.

53. Chakrabarti S, Fombonne E. Pervasive developmental disorders in preschool children: Confirmation of high prevalence. Am J Psychiatry. 2005;162(6):1133-41. doi.org/10.1176/appi.ajp.162.6.1133.

54. Gernsbacher MA, Morson EM, Grace EJ. Language and Speech in Autism. Annu Rev Linguist. 2016;2(1):413-25. doi.org/10.1146/annurev-linguistics-030514-124824.

55. Ledesma RD, Valero-Mora P. Determining the number of factors to retain in EFA: An easyto-use computer program for carrying out Parallel Analysis. Pract Assessment, Res Eval. 2007;12(2):1-11.

56. Lloret S, Ferreres A, Tomás AH e. I. El análisis factorial exploratorio de los ítems: Análisis guiado según los datos empíricos y el software. An Psicol. 2017;33(2):417-32. doi.org/10.6018/analesps.33.2.270211.

57. Volkmar F, Chawarska K, Klin A. Autism in Infancy and Early Childhood. Annu Rev Psychol. 2005;56(1):315-36. doi.org/10.1146/annurev.psych.56.091103.070159.

58. Gómez JC. Hand Leading and Hand Taking Gestures in Autism and Typically Developing Children. J Autism Dev Disord. 2015;45(1):68-74. doi.org/10.1007/s10803-014-2305-5. 
59. Mandy WPL, Skuse DH. Research Review: What is the association between the socialcommunication element of autism and repetitive interests, behaviours and activities? J Child Psychol Psychiatry. 2008;49(8):795-808. doi.org/10.1111/j.1469-7610.2008.01911. x.

60. Lorenzo-Seva U, Ferrando PJ. Robust Promin: A method for diagonally weighted factor rotation. Lib Rev Peru Psicol. 2019;25(1):99-106. doi.org/10.24265/liberabit. 2019.v25n1.08.

61. Volkmar F, McPartland JC. From Kanner to DSM-5: Autism as an Evolving Diagnostic Concept. Annu Rev Clin Psychol. 2014;10(1):193-212. doi.org/10.1146/annurev-clinpsy032813-153710.

62. Costello AB, Osborne JW. Best practices in Exploratory Factor Analysis: Four Recommendations for Getting the Most from Your Analysis. Pract Assessment, Res Eval. 2005;10(7):1-9.

63. Lord C, Luyster R, Gotham K, Guthrie W. Autism diagnostic observation schedule, (ADOS2) manual (Part II): Toddler module. Los Angeles: Western Psychological Services; 2012. 


\section{Figures}

Figure 1. Histogram of Q-CHAT total scores distribution in the studied sample $(n=188)$

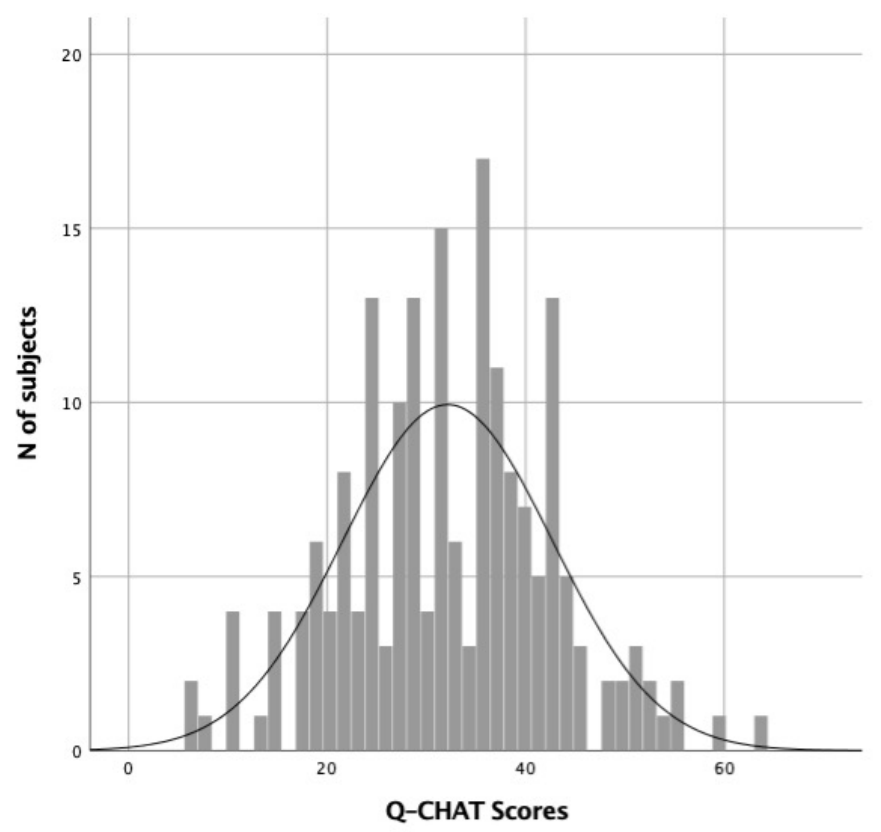

Figure 2. Q-Q Plot for Q-CHAT total scores in the studied sample $(\mathrm{n}=188)$

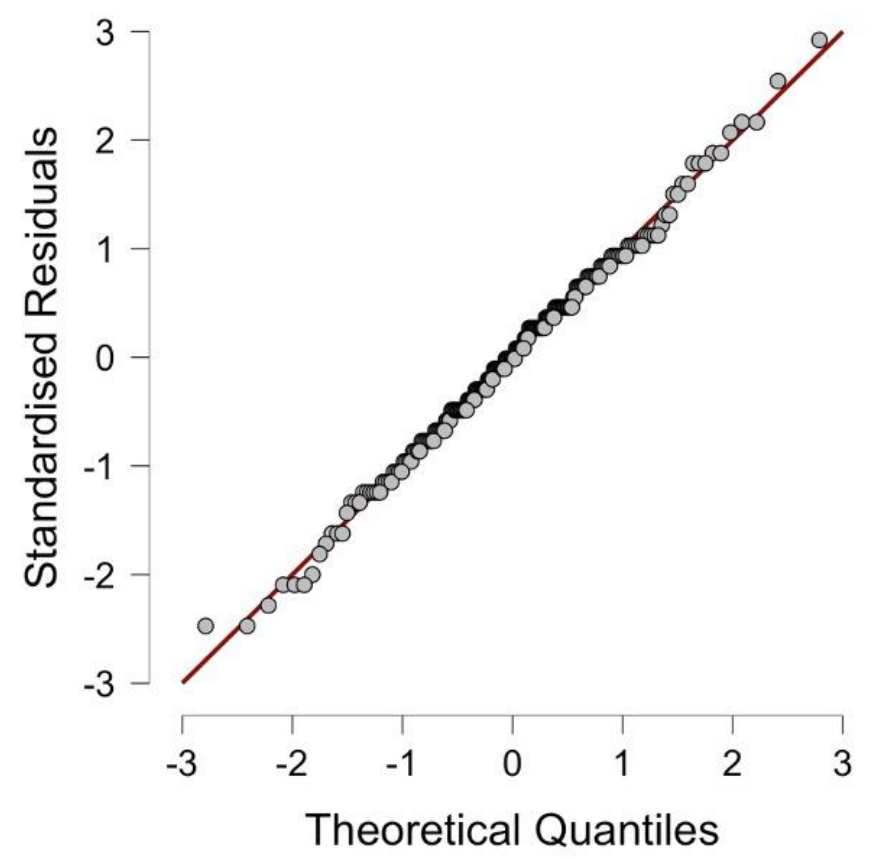




\section{Supporting information}

S1 File. Version of the Q-CHAT translated and adapted cross-culturally in Chile.

\section{Q-CHAT}

Por favor responda las siguientes preguntas pensando en su niño/a, marcando con una cruz la alternativa más apropiada.

Intente contestar TODAS las preguntas.

RECUERDE: no existen respuestas buenas ni malas.

Nombre del niño:

¿Cual es la edad del niño?: meses.

¿Cual es su edad?: años.

¿Cuántas horas pasa usted al día con el niño?:

¿Cual es su relación con el niño?:

\begin{tabular}{|l|l|l|l|l|l|l|l|l|}
\hline Madre & Padre & Abuela & Abuelo & Tía & Tío & Hermana & Hermano & Otro: \\
\hline
\end{tabular}

¿Qué nivel de escolaridad tiene usted?:

\begin{tabular}{|l|l|l|l|l|l|}
\hline $\begin{array}{l}\text { Básica } \\
\text { Incompleta }\end{array}$ & $\begin{array}{l}\text { Básica } \\
\text { Completa }\end{array}$ & $\begin{array}{l}\text { Media } \\
\text { Incompleta }\end{array}$ & $\begin{array}{l}\text { Media } \\
\text { Completa }\end{array}$ & $\begin{array}{l}\text { Superior } \\
\text { Técnica }\end{array}$ & $\begin{array}{l}\text { Superior } \\
\text { Profesional }\end{array}$ \\
\hline
\end{tabular}

Allison, Baron-Cohen, Wheelwright, Charman, Richler, Pasco and Brayne, (2008). 
1. ¿Su niño/a lo/a mira a usted cuando lo llama por su nombre?
O siempre
O muchas veces
$O$ a veces
O pocas veces
O nunca

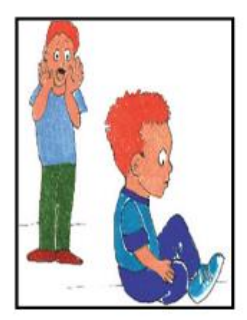

2. ¿Que tan fácil es para usted tener contacto visual con su niño/a?. Por ejemplo, que el/ella le mire.

O muy fácil

O bastante fácil

O bastante difícil

O muy difícil

O imposible

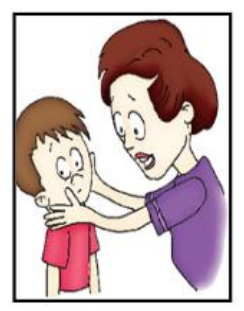

3. Cuando su niño/a está jugando solo/a, ¿ ordena en fila sus juguetes u objetos?

O siempre

O muchas veces

$O$ a veces

$O$ pocas veces

O nunca

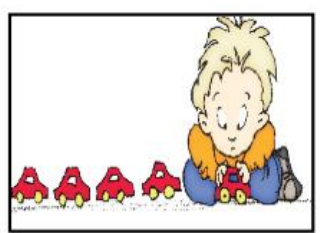

4. ¿Otras personas pueden entender fácilmente a su niño/a cuando habla?

O siempre

O muchas veces

$O$ a veces

$O$ pocas veces

O nunca

O mi niño/a no habla

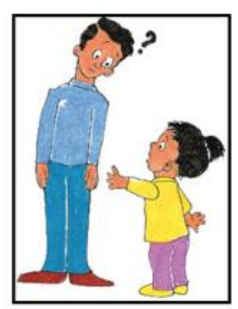

5. ¿Su niño/a apunta con el dedo cuando quiere algo? Por ejemplo, un juguete que está fuera de su alcance.

O siempre

O algunas veces por día

O pocas veces por semana

O menos de una vez por semana

O nunca

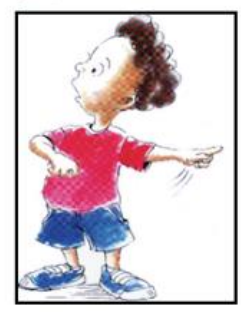


6. ¿Su niño/a apunta con el dedo para mostrarle algo que le interesa? Por

ejemplo, apunta para mostrarle o compartir algo interesante.

O siempre

O algunas veces por día

$O$ pocas veces por semana

O menos de una vez por semana

O nunca

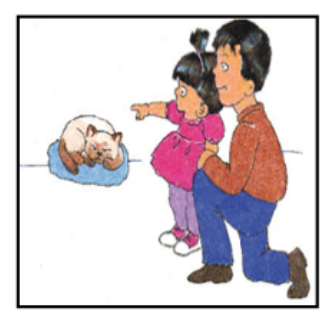

7. ¿Cuánto tiempo puede estar su niño/a mirando un objeto que está girando? Por ejemplo, un ventilador o las ruedas de un autito de juguete.

V varias horas

O media hora

O diez minutos

$O$ un par de minutos

$O$ menos de un minuto

8. ¿Cuántas palabras puede decir su niño/a?

O ninguna-no ha comenzado a hablar todavía

O menos de 10 palabras

O 10-50 palabras

O 51-100 palabras

más de 100 palabras

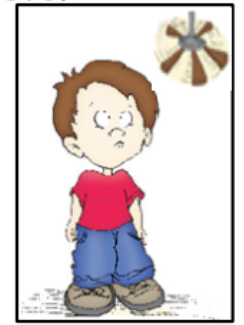

9. ¿Su niño/a juega a simular?. Por ejemplo, hacer "como si" cuidara su muñeca o "como si" hablara por un teléfono de juguete.

O siempre

algunas veces por día

$O$ pocas veces por semana

$O$ menos de una vez por semana

O nunca

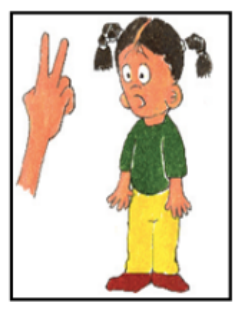

10. ¿Su niño/a sigue su mirada hacia donde usted está mirando?

O siempre

O algunas veces por día

$O$ pocas veces por semana

$O$ menos de una vez por semana

O nunca
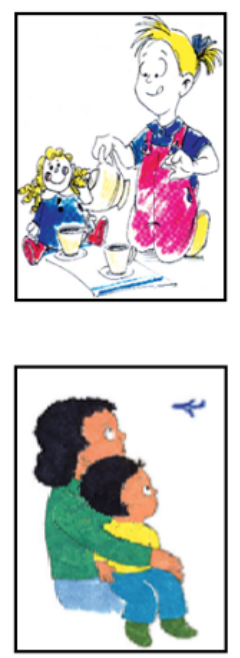
11. ¿Con qué frecuencia su niño/a huele o lame objetos extraños?.

O siempre

O algunas veces por día

$O$ pocas veces por semana

O menos de una vez por semana

O nunca

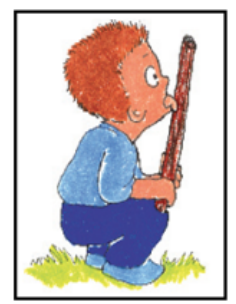

12. ¿Su niño/a coloca su mano en un objeto cuando él quiere que usted lo utilice? Por ejemplo, en la manilla de una puerta cuando él quiere que usted la abra o en un juguete cuando él quiere que usted lo haga funcionar.

O siempre

O algunas veces por día

$O$ pocas veces por semana

menos de una vez por semana

O nunca

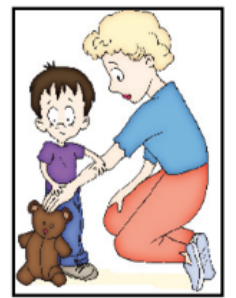

13. ¿Con qué frecuencia su niño/a camina en punta de pies?

O siempre

O muchas veces

O a veces

O pocas veces

O nunca

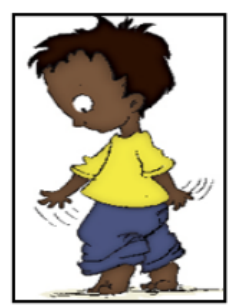

14. ¿Qué tan fácil es para su niño/a, adaptarse cuando sus rutinas cambian o cuando algunas cosas están fuera del lugar habitual?

muy fácil

O bastante fácil

O bastante difícil

muy difícil

imposible

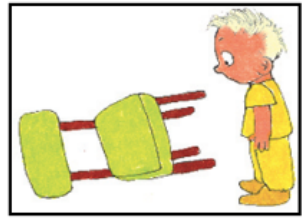

15. Si usted o alguien en su familia está visiblemente angustiado o triste, ¿Su niño/a muestra signos de querer ayudarlo?. Por ejemplo, acariciando su pelo o abrazándolo.

O siempre

O muchas veces

$O$ a veces

O pocas veces

O nunca

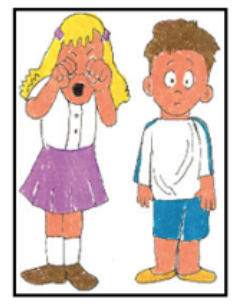


16. ¿Su niño/a hace la misma cosa una y otra vez?. Por ejemplo, abrir la llave del agua, apagar y prender luces o cerrar y abrir las puertas.

O siempre

O algunas veces por día

O pocas veces por semana

menos de una vez por semana

O nunca

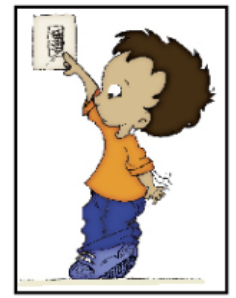

17. ¿Cómo describiría usted las primeras palabras de su niño?

O muy típicas

O típicas

O extrañas

O muy extrañas

O mi niño/a no habla

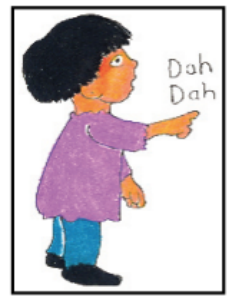

18. ¿Cuántas veces su niño/a repite "como un eco" las cosas que ha escuchado?. Por ejemplo, palabras de canciones, frases de películas o sonidos.

O siempre

algunas veces por día

$O$ pocas veces por semana

O menos de una vez por semana

O nunca

Anote un ejemplo

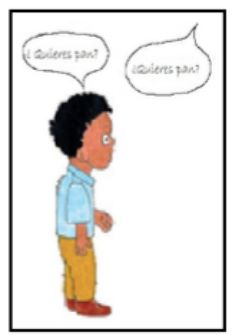

19. ¿Su niño/a utiliza gestos simples?. Por ejemplo, cuando se despide, ¿hace como "chao"?

O siempre

O algunas veces por día

$O$ pocas veces por semana

menos de una vez por semana

O nunca

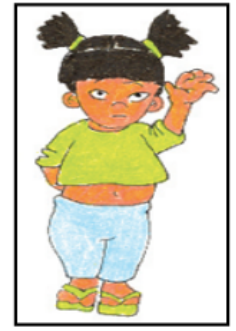

20. ¿Su niño/a hace movimientos raros con sus dedos frente a sus ojos?

O siempre

$O$ algunas veces por día

$O$ pocas veces por semana

$O$ menos de una vez por semana

O nunca

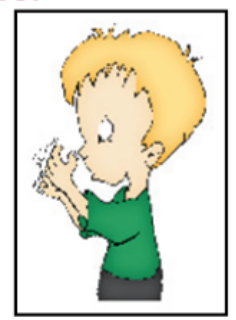


21. ¿Su niño/a le mira espontáneamente a la cara para ver su reacción, cuando ocurre algo que no es habitual?

O siempre

O muchas veces

$O$ a veces

O pocas veces

O nunca

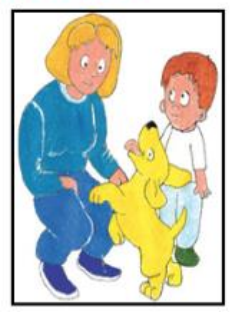

22. ¿Durante cuánto tiempo su niño/a se puede mantener interesado solamente en uno o dos objetos?

O la mayor parte del día

O varias horas

O media hora

O diez minutos

$O$ un par de minutos

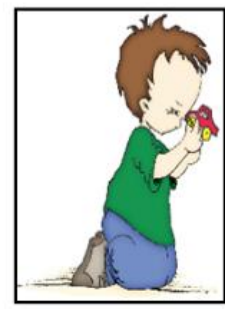

23. ¿Su niño/a hace girar o agita objetos repetitivamente?. Por ejemplo, utilizando un pedacito de hilo.

O siempre

algunas veces por día

$O$ pocas veces por semana

$O$ menos de una vez por semana

O nunca

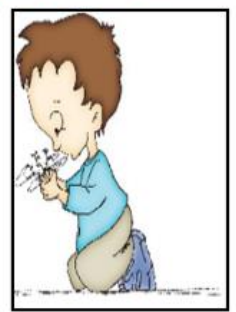

24. ¿Es tu niño/a demasiado sensible a los ruidos?

O siempre

O muchas veces

$O$ a veces

O pocas veces

O nunca

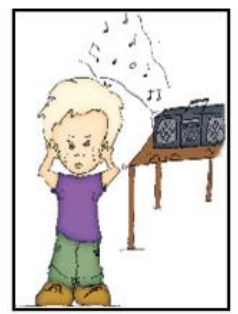

Anote un ejemplo

25. ¿Tu niño/a mira a la nada, como sin propósito aparente?. Por ejemplo, mirando un punto fijo.

O siempre

O algunas veces por día

$O$ pocas veces por semana

$O$ menos de una vez por semana

O nunca

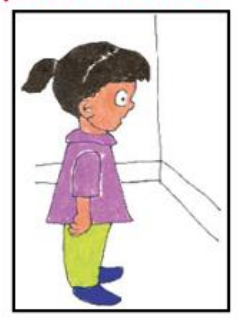

